\title{
Nepeta transcaucasica Grossh. (kaf pisikotu) Estraktının HPLC ile Fenolik Madde İçeriğinin Tayini, Antimikrobiyal, Antioksidan ve DNA Koruyucu Aktivitelerinin Belirlenmesi
}

\author{
Ahmet SAVCI ${ }^{1} \mathscr{\&}$, Enver Fehim KOÇPINAR ${ }^{2}$, Yusuf ALAN ${ }^{3}$, Murat KURSAT $^{4}$ \\ ${ }^{1}$ Moleküler Biyoloji ve Genetik, Fen-Edebiyat Fakültesi, Muş Alparslan Üniversitesi, Muş, Türkiye \\ ${ }^{2}$ Tıbbi Laboratuvar Teknikleri, Sağlık MYO, Muş Alparslan Üniversitesi, Muş, Türkiye \\ ${ }^{3}$ Temel Eğitim Bölümü, Eğitim Fakültesi, Muş Alparslan Üniversitesi, Muş, Türkiye \\ ${ }^{4}$ Biyoloji, Fen-Edebiyat Fakültesi, Bitlis Eren Üniversitesi, Bitlis, Türkiye \\ $\triangle$ : a.savci@alparslan.edu.tr, (iD) 10000-0002-9609-785X, (ID)20000-0002-6031-4664, (D)3 0000-0003-0007-0212, \\ 0000-0002-0861-4213
}

Geliş (Received):18.09.2020

Düzeltme (Revision):19.11.2020

Kabul (Accepted): 03.12.2020

\section{ÖZ}

Lamiaceae familyasının üyeleri içerdikleri sekonder metabolitler sayesinde geleneksel tıpta ve tarımda yaygın bir şekilde kullanılmaktadırlar. Bu çalışmada, Bitlis İlinde toplanan Nepeta transcaucasica Grossh. (kaf pisikotu) bitkisinden elde edilen etanol ekstraktının fenolik madde içeriği HPLC ile belirlenerek, antimikrobiyal, antioksidan ve DNA koruyucu aktiviteleri araştırıldı. Ekstraktın en fazla apigenin ve vanillin içerdiği belirlendi. Antimikrobiyal aktivite sonuçlarına göre genel olarak değerlendirildiğinde iyi derecede aktivite gösterdiği gözlemlendi. Aynı zamanda ekstraktın eritromisin hariç diğer antibiyotiklerden daha iyi antibakteriyal aktivite gösterdiği düşünülmektedir. Çalışmada, ekstraktın in vitro antioksidan özelliklerini belirlemek amacıyla dört farklı metot kullanıldı. Çalışmanın sonucuna göre $N$. transcaucasica ekstraktının, BHA, BHT ve $\alpha$-tokoferol standart antioksidanlarına yakın antioksidan aktivite sergilediği belirlendi. Son olarak ekstraktın, pBR322 DNA plazmiti üzerine koruyucu etki göstermediği gözlendi. N. transcaucasica ile ilgili çalışmalar kısıtlı olduğundan, bu çalışmada elde edilen sonuçların literatüre önemli katkılar sunacağı düşünülmektedir.

Anahtar Kelimeler: Antimikrobiyal, antioksidan, bitki, DNA, HPLC

\section{Determination of Phenolic Content by HPLC, Antimicrobial, Antioxidant and DNA Protective Activities of Nepeta transcaucasica Grossh. (kaf pisikotu) Extract}

\begin{abstract}
Members of the Lamiaceae family are widely used in traditional medicine and agriculture thanks to their secondary metabolites. In this study, the phenolic substance content of ethanol extract obtained from Nepeta transcaucasica Grossh. (kaf pisikotu) plant collected in Bitlis province was determined by HPLC and antimicrobial, antioxidant and DNA protective activities were investigated. It was determined that the extract contained the most apigenin and vanillin. When evaluated according to the antimicrobial activity results, it was observed that it showed good activity. It was also found that the extract showed better antibacterial activity than other antibiotics except erythromycin. Four different methods were used to determine the in vitro antioxidant properties of the extract. According to the results of the study, it was determined that $N$. transcaucasica extract exhibited antioxidant activity close to BHA, BHT and $\alpha$-tocopherol standard antioxidants. Finally, it was observed that the extract had no protective effect on the pBR322 DNA plasmid. Since the studies on N. transcaucasica are limited, it is thought that the results obtained in this study will make important contributions to the literature.
\end{abstract}

Keywords: Antimicrobial, antioxidant, DNA, HPLC, plant

GİRIŞ

Geleneksel tıp, tarım, aromaterapi, alternatif tıp gibi çeşitli kullanım alanları olan Lamiaceae familyasının [1], 250'ye yakın cinsi ve 3200'ü aşkın türü mevcuttur. Ülkemizin en zengin 3. familyası olan bu familya, 46 cins ve 758 takson ile temsil edilmekte olup endemizm oranı \% 45'tir [2]. Lamiaceae familyasının önemli bir üyesi olan Nepeta cinsi; Avrupa, Asya ve Afrika'da yayılan 280 tür içerir. Türkiye'de 33 tür ve 19'u endemik olmak üzere toplam 40 taksonla temsil edilmektedir. $\mathrm{Bu}$ türlerden bazıları tıbbi özellikleri ve biyolojik aktiviteleri ile tanınmaktadır. Halk hekimliğinde idrar söktürücü, terletici, antispazmodik, anti-astım, yatıştırıcı ve mide rahatsızlıklarını tedavi etmede kullanılırlar [3]. Tibbi öneme sahip olan Lamiaceae familyasına ait bitkiler, içerdikleri sekonder metabolitlerden dolayı büyük önem taşımaktadır. Daha önceki çalışmalarda familyanın; antimikrobiyal [4], antifungal [5], antiinflamatuar [6], antikanser, antioksidan [7, 8] gibi çeşitli biyolojik aktiviteleri bulunduğu rapor edilmiştir. $\mathrm{Bu}$ çalışmada Lamiaceae familyasına ait olan Nepeta transcaucasica Grossh. (kaf pisikotu) toprak üstü 
kısımlarından etanol ekstraktı elde edilerek, sekonder metabolit olan 14 farklı fenolik madde miktarı Yüksek Performanslı Sıvı Kromatografi (HPLC) ile belirlendi. Üç gram pozitif, dört gram negatif bakteri ve üç adet fungusun dahil olduğu 10 farklı mikroorganizma üzerindeki antimikrobiyal etkileri oyuk agar yöntemi ile araştırıldı. Ayrıca ekstraktın antioksidan aktivitesi ve DNA üzerindeki koruyucu aktivitesi araştırıldı.

\section{MATERYAL ve YÖNTEM}

\section{Bitki örneklerinin toplanması ve ekstraksiyonu}

Çalışmada kullanılan $N$. transcaucasica bitkisi, vejetasyon dönemlerinde 2014-2015 yılları arasında toplandı (Van, Erçiş, Deli çay çevresi, $1850 \mathrm{~m}, 39^{\circ}$ $\left.02^{\prime} 07^{\circ} \mathrm{N}, 43^{\circ} 29^{\prime} 17^{\circ} \mathrm{E}\right)$. Toplanan bitki örnekleri Bitlis Eren Üniversitesi, Bilim ve Teknoloji Uygulama ve Araştırma Merkezi Laboratuvarı'nda herbaryum materyali haline getirilerek (M.KURŞAT: 6045) koduyla saklanmaktadır. Bitki örneklerinden 50'şer gr alınıp soxhlet cihazı yardımıyla etanol ekstraktı elde edildi ve $-18^{\circ} \mathrm{C}$ 'de muhafaza edildi.

\section{HPLC ile fenolik madde analizi}

Fenolik madde miktarının belirlenmesi amacıyla, gallik asit, kurkumin, katekol, askorbik asit, vanilin, mirisetin, absisik asit, kuersetin, apigenin, kemferol, kafeik asit, sinnamik asit, salisilik asit ve rozmarinik asitin son konsantrasyonu $10 \mathrm{mg} / \mathrm{ml}$ olacak şekilde hazırlandı. $\% 1$ 'lik asetik asit ile $1 / 9$ oranında asetonitril ilave edilerek çözelti hazırlandı. Çözeltiye $1 / 1$ oranında metanol ilave edilerek standartları çözmek için gerekli olan stok çözelti hazırlandı. Stok çözeltiler 5 farklı oranda (100 mM, $75 \mathrm{mM}, 50 \mathrm{mM}, 25 \mathrm{mM}$ ve $10 \mathrm{mM})$ hazırlandı [9]. N. transcaucasica ekstraktını HPLC'ye yüklemek için gerekli prosedür önceki çalışmamıza göre yapild1 [10].

\section{Antimikrobiyal aktivite tayini}

Dimetil sülfoksit (DMSO)'da çözdürülen $N$. transcaucasica ekstraktının antimikrobiyal aktivite tayini oyuk agar yöntemi ile yapıldı [11]. Bu çalışmada Staphylococcus aureus ATCC 25923, Bacillus subtilis ATCC 6633, Bacillus megaterium DSM 32, Eshericha coli ATCC 11229, Enterobacter aerogenes ATCC 13048, Pseudomonas aeroginosa ATCC 9027, Klebsiella pneumonia ATCC 13883, Yarrowia lipolytica, Saccharomyces cereviciae ve Candida albicans ATCC 10231 mikroorganizmaları kullanıldı. Test mikroorganizmaları Muş Alparslan Üniversitesi Merkezi Laboratuvarı'ndan temin edildi. Ekstraktın üç farklı miktarı $(75 \mu \mathrm{l}, 100 \mu \mathrm{l}$ ve $150 \mu \mathrm{l})$ kullanıldı. Test bakteri ve mayaların $\left(10^{6} \mathrm{CFUs} / \mathrm{ml}\right)$ bulanıklığ $1 \mathrm{Mc}$ Farland 0,5 standartına göre ayarlandı [12]. Antibiyotiklerle kıyaslamak için Oxoid'ten temin edilen, Eritromisin (E-15), Ampisillin/sulbaktam (SAM20), Rifampisin (RD-5), Amikasin (AK-30) ve Fluconazol (FCA-25) kullanıldı. Meydana gelen inhibisyon zonlarının çapı mm cinsinden ölçüldü.

\section{Antioksidan Özellikler}

Ferrik tiyosiyanat metoduna göre total antioksidan aktivite tayini

Çalışmada, lipit peroksidasyonunu inhibe etme yüzdelerini belirlemek için tiyosiyanat metodu kullanıld1 [13]. Farklı konsantrasyonlarda stok çözelti, deney tüplerine pipetlendi ve hacim tampon çözeltiyle (pH: 7,4) 2,5 ml'ye tamamland. Ardından tüplere 2,5 $\mathrm{ml}$ linoleik asit emülsiyonu ilave edildi. $37{ }^{\circ} \mathrm{C}$ 'de inkübasyona birakılan örneklerden her on saatte bir 100 'er $\mu \mathrm{l}$ alınd1, 4,7 $\mathrm{ml}$ etanol bulunan deney tüplerine konuldu. $100 \mu \mathrm{Fe}^{2+}$ ve $100 \mu \mathrm{SCN}^{-}$çözeltisi ilave edildi. Spektrofotometrede $500 \mathrm{~nm}$ 'de absorbanslar köre karş1 okundu. Kontrol maksimum absorbansa ulaşınca deney sonlandırıldı. Standart antioksidanlardan Bütillenmiş hidroksianisol (BHA), Bütillenmiş hidroksitoluen (BHT) ve E vitamini ( $\alpha$-tokoferol) kullanıld1.

\section{Total indirgeme kuvveti tayini}

$\mathrm{Fe}^{+3}$ iyonunun $\mathrm{Fe}^{+2}$ iyonuna indirgenme gücünün tayini Oyaizu yöntemine göre yapıldı [14]. Stok çözeltilerden 25,50 ve $100 \mu \mathrm{g} / \mathrm{ml}$ olacak şekilde örnekler alındı ve test tüplerine aktarıld 1 , ardından hacim saf suyla $1 \mathrm{ml}$ 'ye tamamlandi. Daha sonra her bir tüpe $2,5 \mathrm{ml} \mathrm{0,2 \textrm {M }}$ tampon çözelti (pH: 6,6) ve 2,5 ml \% 1 'lik potasyumferrisiyanür $\left[\mathrm{K}_{3} \mathrm{Fe}(\mathrm{CN})_{6}\right]$ ilave edildikten sonra inkübasyona başland $1 \quad\left(50 \quad{ }^{\circ} \mathrm{C}\right.$ 'de $\left.20 \quad \mathrm{dk}\right)$. İnkübasyondan sonra karışımın üzerine $2,5 \mathrm{ml}$ triklorasetik asit (TCA) eklendi. Santrifüj işleminden sonra karışımın üst fazından 2,5 ml alındı ve üzerine 2,5 $\mathrm{ml}$ destile su ve $0,5 \mathrm{ml} \mathrm{FeCl}_{3}$ eklenip, spektrofotmetrede 700 nm'de absorbansları alınd1.

\section{DPPH radikali giderme aktivitesi tayini}

Serbest radikal giderme amaçl1 1,1-Difenil 2-pikril hidrazil (DPPH)'ın 1 mM'lık çözeltisinin kullanıldı ğ bu çalışma Blois metoduna [15] göre yapıldı. Deney tüplerine sirasiyla $25 \mu \mathrm{g} / \mu \mathrm{l}, 50 \mu \mathrm{g} / \mu \mathrm{l}$ ve $100 \mu \mathrm{g} / \mu \mathrm{l}$ konsantrasyonlarında ekstraktlar aktarıldı ve etonul ile toplam hacim üç ml'ye tamamland. DPPH• çözeltisinden tüplere birer $\mathrm{ml}$ ilave edilerek yarım saat inkübe edildi. Spektrofotometre kullanılarak 517 nm'de absorbansları kaydedildi.

\section{Kuprak metoduna göre indirgeme kuvveti tayini}

Ekstrakt ve standartların kuprik iyonu $\left(\mathrm{Cu}^{2+)}\right.$ indirgeme kapasiteleri Apak ve arkadaşlarının kullandığı Kuprak metodunun [16] hafif bir modifikasyonuna göre yapıldı. Deney tüplerine $0,25 \mathrm{ml} \mathrm{CuCl}_{2}$ çözeltisi ilave edildikten sonra üzerine $0,25 \mathrm{ml} 7,5 \times 10^{-3} \mathrm{M}^{\prime}$ lık etanolik neokuprin çözeltisi ve 1 asetat tamponu aktarıldı. Ardından farklı konsantrasyonlarda $(25 \mu \mathrm{g} / \mu \mathrm{l}, 50 \mu \mathrm{g} / \mu \mathrm{l}, 75 \mu \mathrm{g} / \mathrm{ml})$ numune ve standartlar ilave edildi. Yarım saatlik bir inkübasyondan sonra 450 nm'de absorbansları kaydedildi.

\section{DNA üzerindeki etkileri}

$N$. transcaucasica etanol ekstraktının DNA üzerindeki etkisi pBR322 plazmid DNA kullanılarak agaroz jel elektroforez yöntemi ile belirlendi [11]. Öncelikle ekstraktı, $200 \mathrm{mg} / \mathrm{ml}$ konsantrasyonunda olacak şekilde 
DMSO'da çözdürüldü ve 3 faklı konsantrasyonda (100, 50 ve $25 \mathrm{mg} / \mathrm{ml}$ ) hazırlandı. Çalışmanın totalinde toplam 20 adet PCR tüpü kullanılarak sırasıyla; 1 . pBR322 DNA (200 ng) $10 \mu \mathrm{l}$, 2. Hidrojen peroksit $\left(\mathrm{H}_{2} \mathrm{O}_{2}\right) 5 \mu \mathrm{l}, 3$. DMSO $10 \mu \mathrm{l}, 4$. Etanol ekstraktı $10 \mu \mathrm{lve}$ 5. Tüplerdeki toplam miktar $25 \mu$ l 'ye tamamlanacak şekilde steril saf su ilave edilerek hazırlandı. Örnekler, $37{ }^{\circ} \mathrm{C}$ ' de 24 saat karanlık ortamda inkübe edildi. DNA'nın $5 \mu \mathrm{l}$ ' si yükleme tamponu ile karıştırılıp agaroz jele yüklendi. Elektroforezden sonra görüntüler alind1 [17].

\section{BULGULAR ve TARTIŞMA}

\section{Fenolik madde miktarı tayini}

$N$. transcaucasica fenolik madde içeriklerini belirlemek için 14 farklı fenolik standart kullanılarak miktar analizi HPLC cihazı ile yapıldı. Elde edilen sonuçlar Tablo 1'de verilmiştir. Sonuçlara göre; $N$. transcaucasica ekstraktında en az miktarda kemferol $(1,365 \mu \mathrm{g} / \mathrm{ml})$ var iken, en fazla miktarda ise apigenin $(117,009 \mu \mathrm{g} / \mathrm{ml})$ varlığ 1 tespit edildi. Askorbik asit, gallik asit, vanilin ve salisilik asit varlığına rastlanmadı. Önceki çalışmalarda Lamiaceae familyasına ait bitki türlerinin içeriğinde yüksek oranda rozmarinik asit tespit edilmiştir [18-21]. Nepeta cinsine ait bitkiden elde edilen ekstraktın fenolik madde içeriğine göre en fazla klorojenik asit, rozmarinik asit, kuinik asit, kemferol ve kumarik asit bileşikleri tespit edilmiştir [22]. Çalışmamızda ise $N$. transcaucasica ekstraktında en fazla miktarda sirasıyla apigenin, mirisetin ve rozmarinik asit tespit edildi.

Tablo 1. N. transcaucasica etanol ekstraktının içerdiği fenolik bileşik miktarları $(\mu \mathrm{g} / \mathrm{ml})$

\begin{tabular}{lc}
\hline \multicolumn{1}{c}{ Fenolikler } & $\boldsymbol{\mu g} / \mathbf{m l}$ \\
\hline Askorbik asit & SY \\
Gallik asit & SY \\
Mirisetin & 50,666 \\
Absisik Asit & 1,942 \\
Kuersetin & 10,617 \\
Apigenin & 117,009 \\
Kemferol & 1,365 \\
Kurkumin & 6,500 \\
Katekol & 18,120 \\
Vanilin & SY \\
Kafeik asit & 6,527 \\
Sinnamik asit & 1,416 \\
Rozmarinik asit & 30,513 \\
Salisilik asit & SY \\
SY: Sonuç Yok &
\end{tabular}

\section{Antimikrobiyal aktivite çalışmaları}

$N$. transcaucasica ekstraktının ve antibiyotiklerin mikroorganizmalar üzerindeki etkilerinin sonuçları Tablo 2A ve 2B'de gösterildi. Mikroorganizmalara karş1 $N$. transcaucasica ekstraktı incelendiğinde $C$. albicans'a $(27 \pm 1,73 \mathrm{~mm})$ karş1 en iyi aktiviteyi gösterirken, en az aktiviteyi ise $E$. coli' ye $(12 \pm 0,00 \mathrm{~mm})$ karşı gösterdiği tespit edildi. Aynı zamanda konsantrasyon artışına bağlı olarak ekstraktın aktivitesinin arttığı gözlemlendi. Ekstraktın $K$. pneumonia'ye karşı herhangi bir antibakteriyal etki göstermediği gözlemlendi. Lamiaceae familyasına ait bitkilerin metanol ve etanol ekstraktlarının $S$. aureus ve $B$. subtilis üzerinde antimikrobiyal etki gösterdiği belirlenmiştir [23]. Nepeta ile yapılan çalışmada metanol ekstraktının en yüksek antibakteriyel aktiviteyi $B$. megaterium'a, en düşük aktiviteyi ise $B$. subtilis ve $E$. coli'ye karşı gösterdiği rapor edilmiştir [22]. Lamiaceae familyasına ait başka bir çalışmada su ekstraktı hariç diğer ekstraktların antibakteriyal aktivite gösterdiği belirlenmiştir [24]. Nepeta cinsine ait bir başka bitkinin etanol ekstraktının $S$. cereviciae'ye karşı en yüksek aktiviteyi gösterdiği, $Y$. lipolytica' ya karşı hiçbir aktivite göstermediği tespit edilmiştir [18]. Bu çalışmada $N$. transcaucasica ekstraktı ise en iyi aktiviteyi $C$. albicans'a karş1 gösterdiği belirlendi. N. transcaucasica etanol ekstraktının, kontrol grubu olarak kullanılan konsantrasyondaki antibiyotiklerle karşılaştırıldığında, eritromisin hariç diğer antibiyotiklerden daha iyi antibakteriyal aktivite gösterdiği söylenebilir. Ayrıca $N$. transcaucasica ekstraktının $C$. albicans'a karşı flukonazol'den daha iyi antifungal aktivite gösterdiği tespit edildi.

Daha önce yapılan bir çalışmada Lamiaceae familyasına ait ekstraktların, ampicillin ve kanamisin antibiyotiklerinden daha az oranda aktivite gösterdiği tespit edilmiştir [25]. Lamiaceae familyasına ait başka bir çalışmada ise elde edilen ekstraktların kontrol amaçlı olarak kullanılan antibiyotiklerden daha az aktivite gösterdikleri belirtilmiştir [24]. Bazı çalışmalarda Nepata cinsine ait bitki ekstraktlarının antibiyotiklerden daha az aktivite gösterdikleri rapor edilmiştir [18, 22]. Bir başka çalışmada ise Nepeta transcaucasica metanol ekstraktının standart olarak kullanılan ilaçtan daha iyi antimikrobiyal etki gösterdiği belirlenmiştir [26]. Bu çalışmada ise ekstraktın, eritromisin hariç diğer antibiyotiklerden daha iyi antimikrobiyal aktivite gösterdiği tespit edildi.

\section{Antioksidan özellikler \\ Total antioksidan aktivite sonuçlart}

$N$. transcaucasica etanol ekstraktı DMSO'da çözdürülerek total antioksidan aktiviteleri "Ferrik Tiyosiyanat Metoduna" göre belirlendi. $N$. transcaucasica total antioksidan aktivite tayini için sirasiyla $25 \mu \mathrm{g} / \mathrm{ml}, \quad 50 \mu \mathrm{g} / \mathrm{ml}$ ve $100 \mu \mathrm{g} / \mathrm{ml}$ konsantrasyonları kullanıldı (Şekil 1). Şekilde de görüldüğü gibi örneklerin total antioksidan aktivitesi, numune konsantrasyonu ile genellikle doğru orantılı olarak artt1.

Numunelerin linoleik asit emülsiyonunu inhibe etme yüzdeleri, kontrol değerinin maksimuma ulaştığı inkübasyon anı olan yirminci saat baz alınarak hesaplandı. Hesaplamalar aşağıdaki eşitliğe göre yapild.

Lipit peroksidasyonu inhibisyonu $(\%)=100-(\mathrm{Ae} / \mathrm{Ak} \mathrm{x}$ 100) 
Tablo 2. A) N. transcaucasica ekstrakt konsantrasyonuna bağlı olarak antimikrobiyal etki yarıçapları (mm). B) antibiyotiklerin konsantrasyona bağlı antimikrobiyal etki yarıçapları (mm)

\begin{tabular}{|c|c|c|c|c|c|c|c|c|c|}
\hline \multicolumn{5}{|l|}{$\mathbf{A}$} & \multicolumn{5}{|l|}{ B } \\
\hline \multirow{2}{*}{\multicolumn{2}{|c|}{ Mikroorganizmalar }} & \multicolumn{3}{|c|}{ N. transcaucasica ekstraktı } & \multicolumn{5}{|c|}{ Antibiyotikler } \\
\hline & & $75 \mu \mathrm{l}$ & \multirow{2}{*}{$\frac{100 \mu \mathrm{l}}{-}$} & $150 \mu \mathrm{l}$ & $\begin{array}{c}\text { Eritromisin } \\
\quad(\text { E-15) }\end{array}$ & $\begin{array}{c}\text { Ampisillin/ } \\
\text { sulbactam } \\
\text { (SAM-20) }\end{array}$ & $\begin{array}{c}\text { Amikasin } \\
\text { (AK-30) }\end{array}$ & $\begin{array}{c}\text { Rifampisin } \\
\text { (RD-5) }\end{array}$ & $\begin{array}{r}\text { Flukonazol } \\
\text { (FCA-25) }\end{array}$ \\
\hline \multirow{3}{*}{ 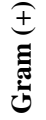 } & B. subtilis & -1 & & $13 \pm 1,00$ & $20 \pm 0,00$ & $14 \pm 1,15$ & $11 \pm 1,00$ & $21 \pm 0,00$ & - \\
\hline & S. aureus & $15 \pm 0,00^{2}$ & $17 \pm 0,57$ & $19 \pm 1,00$ & $21 \pm 1,00$ & $10 \pm 0,00$ & $9 \pm 0,00$ & $18 \pm 1,15$ & - \\
\hline & B. megaterium & $12 \pm 0,00$ & $14 \pm 1,00$ & $18 \pm 1,52$ & $25 \pm 0,00$ & - & $10 \pm 1,00$ & $16 \pm 0,00$ & - \\
\hline \multirow{4}{*}{ I } & E. aerogenes & - & - & $15 \pm 0,57$ & $27 \pm 1,00$ & $10 \pm 1,00$ & $9 \pm 0,00$ & $16 \pm 1,00$ & - \\
\hline & E. coli & - & - & $12 \pm 0,00$ & $19 \pm 1,52$ & $13 \pm 0,00$ & $13 \pm 0,00$ & $18 \pm 0,00$ & - \\
\hline & P. aeroginosa & $12 \pm 0,00$ & $14 \pm 0,57$ & $15 \pm 1,00$ & $19 \pm 0,00$ & - & $14 \pm 1,15$ & $8 \pm 0,00$ & - \\
\hline & K. pneumonia & - & - & - & $19 \pm 1,73$ & $16 \pm 0,57$ & $10 \pm 0,00$ & $19 \pm 1,73$ & - \\
\hline \multirow{3}{*}{ 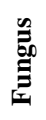 } & Y. lipolytica & $13 \pm 0,00$ & $16 \pm 0,57$ & $17 \pm 1,00$ & - & - & - & - & $21 \pm 0,00$ \\
\hline & C. albicans & $20 \pm 1,00$ & $22 \pm 0,57$ & $27 \pm 1,73$ & - & - & - & - & $23 \pm 1,52$ \\
\hline & S. cereviciae & - & $17 \pm 1,00$ & $19 \pm 0,57$ & - & - & - & - & - \\
\hline
\end{tabular}

${ }^{1}$ : inhibisyon zonu oluşmad1, ${ }^{2}: \mathrm{mm}$ inhibisyon zonu

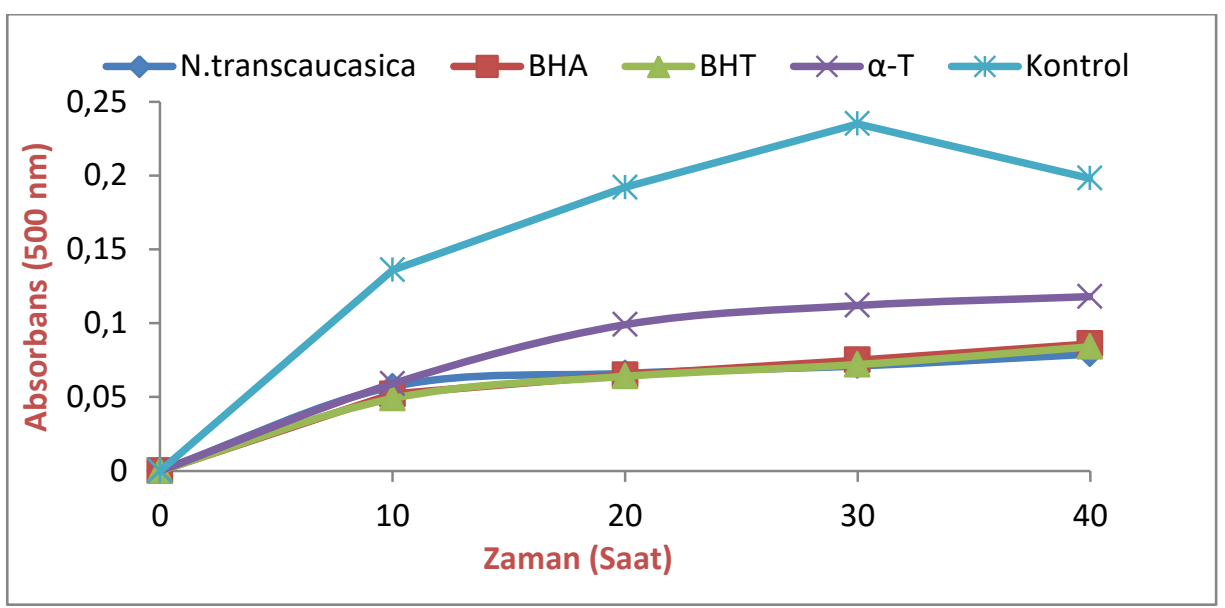

Şekil 1. N. transcaucasica ekstraktının total antioksidan aktivitesinin BHA, BHT ve a-tokoferol ile karşılaştırılması

Burada; Ae: kontrol değerinin maksimuma ulaştığ inkübasyon anındaki ekstraktın verdiği absorbans değeri, Ak ise kontrolün maksimuma ulaştığı inkübasyon anındaki kontrolün verdiği absorbans değerini ifade eder.

$100 \mu \mathrm{g} / \mathrm{ml}$ konsantrasyonunda $N$. transcaucasica linoleik asit emülsiyonu peroksidasyonunu \%71.91 inhibe ederken aynı konsantrasyonda BHA, BHT ve $\alpha$ tokoferol linoleik asit peroksidasyonunu yine sirasiyla $\% 72.34, \% 72.76$ ve $\% 57.87$ oranında inhibe ettikleri gözlenmiştir. Çalışmada kullanılan ekstraktın standart antioksidanlara yakın aktivite gösterdiği saptandı.

\section{Indirgeme Kuvveti Tayini Sonuçlarl (FRAP)}

Ekstraktın ve standartların indirgeme kapasitelerinin konsantrasyona bağlı olarak arttığ 1 görüldü. $25 \mu \mathrm{L}, 50$ $\mu \mathrm{L}$ ve $100 \mu \mathrm{L}$ konsantrasyonlardaki numunelerin indirgeme kuvveti tayini $700 \mathrm{~nm}$ 'de absorbanslarının ölçülmesiyle belirlendi. N. transcaucasica, BHA, BHT ve $\alpha$-tokoferol indirgeme kuvveti kapasiteleri şu şekilde sıralanmaktadır (Şekil 2): BHA > BHT > $\alpha$-tokoferol > N.transcaucasica.

Nepeta'nın faklı bir türüyle yapılan çalışmada FRAP metoduna göre yapılan indirgeme kuvveti sonuçları çalışmamızla benzerlik göstermektedir. Sonuçlara göre indirgeme kuvvetleri şu şekilde sıralanmıştır. BHA > $\mathrm{BHT}>$ Askorbik asit > Nepeta nuda subsp. lydiae etanol ekstresi [22].

DPPH radikal giderme aktivitesi sonuçları

Ekstraktın ve standartların DPPH radikali giderme aktivitesi Şekil 3'de görüldüğü gibi konsantrasyon ile doğru orantılı olarak arttı $N$. transcaucasica ekstraktının $100 \mu$ l'de radikal giderme aktivitesi sonucuna göre, standartlara çok yakın değerde radikal giderme aktivitesi sergilediği tespit edildi.

$N$. transcaucasica ile kullanılan standartlar, $100 \mathrm{Mg} / \mathrm{ml}$ konsantrasyonunda sırasıyla şu şekilde DPPH radikali giderme aktivitesi sergilediler: BHA $(\% 91,74) \geq \alpha$ tocopherol $(\% 91,23) \geq$ BHT $(\% 90,50) \geq N$. transcaucasica $(\% 89,61)$.

Kuprik iyonlarını $\left(\mathrm{Cu}^{2+}\right)$ kupröz iyonlarına $\left(\mathrm{Cu}^{+}\right)$ indirgeme kuvveti sonuçlarl

$N$. transcaucasica etanol ekstraktının, kuprik iyonlarını $\left(\mathrm{Cu}^{2+}\right)$ indirgeme kapasitesinin konsantrasyon artışı ile doğru orantılı olarak arttığı gözlendi. Ekstraktın, $\mathrm{Cu}^{2+}$ iyonlarını indirgeme kapasitesi farklı konsantrasyondaki 


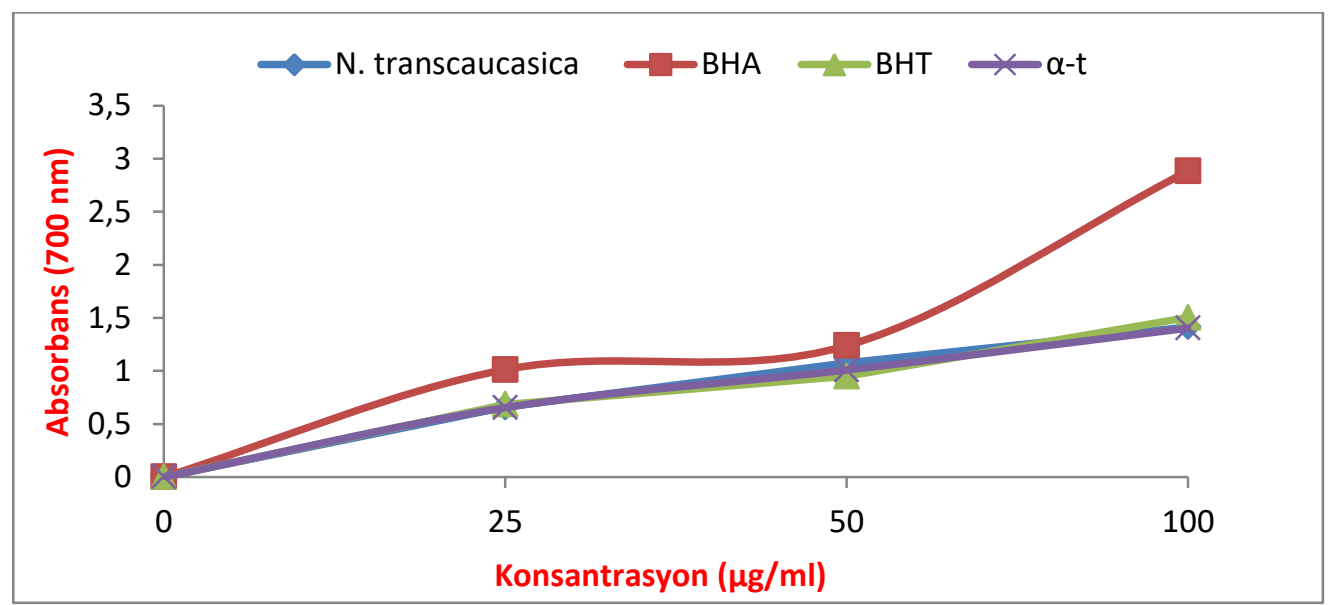

Şekil 2. $N$. transcaucasica etanol ekstraktının indirgeme kuvveti sonuçları

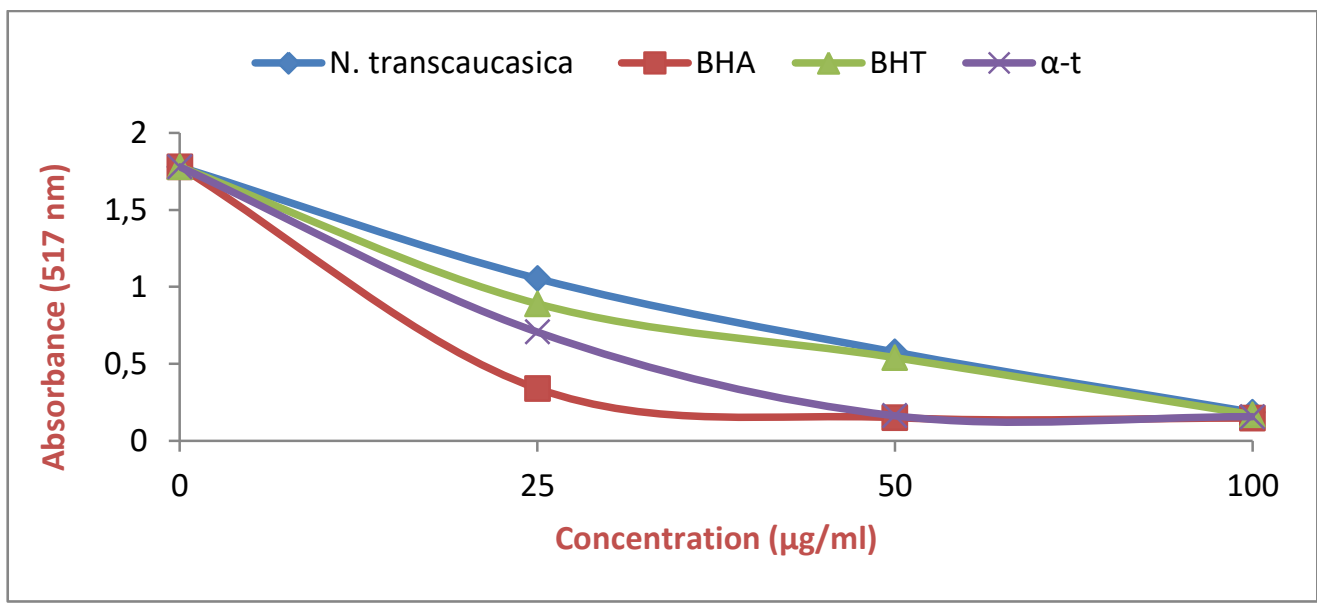

Şekil 3. Farklı konsantrasyonlardaki (25-100 Mg/ml) N. transcaucasica ekstraktının DPPH serbest radikal giderme aktivitesinin BHA, BHT ve a-tokoferol ile karşılaştırılması

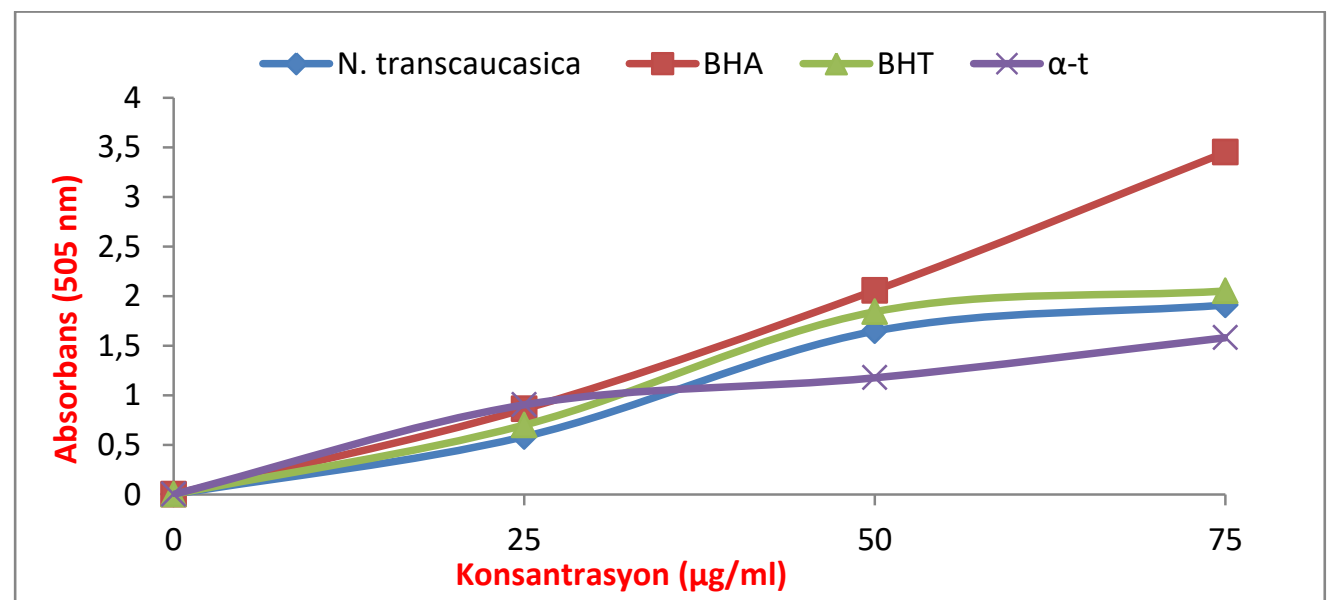

Şekil 4. $N$. transcaucasica etanol ekstraktının farklı konsantrasyonlardaki $(25-75 \mu \mathrm{g} / \mathrm{ml})$ kuprik iyonlarını $\left(\mathrm{Cu}^{2+}\right)$ indirgeme kapasitesinin BHA, BHT ve $\alpha$-tokoferol ile karşılaştırması.

(25-75 $\mu \mathrm{g} / \mathrm{ml})$ çözeltilerinin $450 \mathrm{~nm}$ 'deki absorbansları ölçülerek belirlendi (Şekil 4). Örneklerin $75 \mu \mathrm{g} / \mathrm{ml}$ konsantrasyonundaki indirgeme kapasitesi şu şekilde siraland. BHA $>$ BHT $>N$. transcaucasica $>\alpha-$ tokoferol.Nepeta cinsine ait yapilan in vitro antioksidanların sınırlı sayıda olduğu görüldü. Yapılan bir çalışmada Nepeta nuda subsp. lydiae türünün çalışmamızda kullanılan metotlarla antioksidan aktiviteleri araştırılmıştır. Etanol ve su ekstraktının genel olarak antioksidan aktiviteleri iyi olarak tespit edilmiş ve standartlara yakın aktivitelere sahip olduğu rapor edilmiştir [22]. Başka bir çalışmada $N$. transcaucasica metanol ekstraktının çok güçlü DPPH 
radikal süpürme aktivitesine sahip olduğu (\%80) belirtilmiştir [27].

\section{DNA Koruyucu Aktivite Sonuçları}

Herhangi bir madde veya bitki ekstraktı, plazmid DNA ile etkileştiğinde DNA'nın süper sarmal yapısında (Form I) bir iplikçiği kırılır. Bunun sonucunda DNA gevşek bir yapı oluşturarak agaroz jelde daha yavaş hareket eden, gevşek sarmal DNA (Form II) haline dönüşür. Gevşek yapıdaki sarmal DNA'nın iki iplikçiğinin kopmasıyla Form III olan doğrusal formdaki DNA şekli meydana gelir [28]. Çalışmada kullanılan ekstraktın plazmid DNA ile etkileşimi sonucunda oluşan değişiklikler, Form I, Form II ve Form III dönüşümü gözlemlenerek belirlenebilir.

Elde edilen jel görüntüsüne göre $\mathrm{H}_{2} \mathrm{O}_{2}$ 'nin Form I'i parçaladığı ve DMSO ile birlikte DNA'yı parçaladığ gözlemlendi. DMSO tek başına DNA'ya kısmen etki gösterdi. $N$. transcaucasica ekstraktının konsantrasyona bağlı olarak $\mathrm{H}_{2} \mathrm{O}_{2}+$ DMSO'un süpürücü etkisini ortadan kaldıramadığg görüldü.

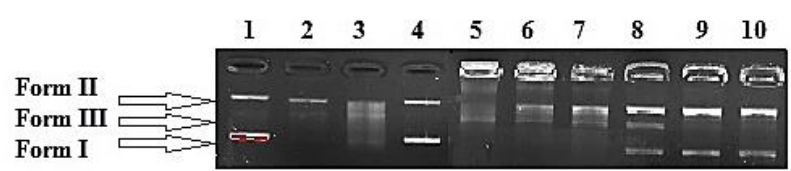

Şekil 5. $N$. transcaucasica etanol ekstraktının DNA koruyucu aktivite görüntüsü. 1. DNA, 2. DNA+ $\mathrm{H}_{2} \mathrm{O}_{2}$, 3. DNA+ $\mathrm{H}_{2} \mathrm{O}_{2}+$ DMSO, 4. DNA + DMSO, 5. DNA $+\mathrm{H}_{2} \mathrm{O}_{2}+$ Ekstrakt $(100 \mathrm{mg} / \mathrm{ml})$, 6. DNA $+\mathrm{H}_{2} \mathrm{O}_{2}+$ Ekstrakt $(50 \mathrm{mg} / \mathrm{ml})$, 7. DNA+ $\mathrm{H}_{2} \mathrm{O}_{2}+$ Ekstrakt $(25 \mathrm{mg} / \mathrm{ml}), 8$. DNA+ Ekstrakt $(100 \mathrm{mg} / \mathrm{ml})$, 9. DNA+ Ekstrakt $(50 \mathrm{mg} / \mathrm{ml})$, 10. DNA+ Ekstrakt $(25$ $\mathrm{mg} / \mathrm{ml})$.

Aynı zamanda $N$. transcaucasica ekstraktının tek başına uygulandığında DNA'nın kararlı halde kalmasını sağladığı tespit edildi. Daha önce yapılan bir çalışmada Lamiaceae familyasına ait bitkilerden elde edilen su ekstraktlarının konsantrasyon miktarlarına bağlı olarak $\mathrm{H}_{2} \mathrm{O}_{2}$ ve UV 1şınları uygulanarak hasara uğratılan pBR322 DNA plazmiti üzerine koruyucu etki gösterdiği belirtilmiştir [29]. Diğer bir çalışmada ise bu familyaya ait bitkilerin uçucu yağlarının plazmid DNA'yı kararlı hale getirdiği bildirilmiştir [30]. Bir başka çalışmada ise Lamiaceae familyasına ait Leucas aspera bitkisinde elde edilen su ekstraktının DNA'yı daha iyi koruduğu tespit edilmiştir [31]. $\mathrm{Bu}$ çalışmada ise ekstraktın pBR322 plazmid DNA üzerinde $\mathrm{H}_{2} \mathrm{O}_{2}+$ DMSO'un süpürücü etkisini ortadan kaldıramadığı gözlendi. $\mathrm{Bu}$ farklılığın farklı bir tür kullanılmasından kaynaklanabileceği düşünülmektedir.

\section{SONUÇ}

Bu çalışmada $N$. transcaucasica etanol ekstraktının HPLC ile fenolik madde miktarları, antimikrobiyal, antioksidan ve DNA koruyucu aktiviteleri araştırıldı. $N$. transcaucasica'ya ait biyolojik aktivitelerinin araştırılmasına ilişkin literatürde çok kısıtlı bulguya ulaşıldı. N. transcaucasica ekstraktının fenolik madde miktarlarına bakıldığında, ekstraktın gallik asit içermediği, en fazla apigenin bulundurduğu belirlendi.
En iyi antimikrobiyal aktiviteyi $C$. albicans'a karşı gösterirken, $K$. pneumonia'e karşı hiçbir antimikrobiyal aktivite göstermediği tespit edildi. Ayrıca ekstraktın eritromisin hariç diğer antibiyotiklerden daha iyi antibakteriyal aktivite gösterdiği söylenebilir. Antioksidan sonuçlara göre ekstraktın güçlü bir antioksidan olduğu ve standart antioksidanlara yakın aktiviteler gösterdiği saptandı. Bununla birlikte ekstraktın DNA üzerinde anlamlı bir koruyucu etkiye sahip olmadığı gözlendi. Genel olarak bakıldığında literatürde bu çalışmada kullanılan $N$. transcaucasica türü ile ilgili yapılan çalışmalar kısıtlı olduğundan elde ettiğimiz verilerin literatüre önemli katkılar sağlayacağ düşünülmektedir.

\section{KAYNAKÇA}

[1] Polat R., Çakılcığlu U., Satıl F. Traditional uses of medicinal plants in Solhan (Bingöl-Turkey). J. of Ethnopharmacology. 148 951-963, 2013.

[2] Başer K.H.C., Kırımer N. Essential Oils of Lamiaceae Plants of Turkey. Acta Horticulturae. 723 163-171, 2006.

[3] İscan G., Köse Y.B., Demirci B., Baser K.H.C. Anticandidal Activity of the Essential Oil of Nepeta transcaucasica Grossh. Chemistry Biodiversity. 8 2144$2148,2011$.

[4] Quave C.L., Plano L.R., Pantuso T., Bennett B.C. Effects of extracts from Italian medicinal plants on planktonic growth, biofilm formation and adherence of methicillinresistant Staphylococcus Aureus. J. of Ethnopharmacology. 118 418-428, 2008.

[5] Figueiredo A.C., Barroso J.G., Pedro L.G., Salgueiro L., Miguel M.G., Faleiro M.L. Portuguese Thymbra and Thymus species volatiles: Chemical composition and biological activities. Current Pharmaceutical Design. 14 3120-3140, 2008.

[6] Takaki I., Bersani-Amado L.E., Vendruscolo A., Sartoretto S.M., Diniz S.P., Bersani-Amado C.A. Antiinflammatory and antinociceptive effects of Rosmarinus officinalis L. essential oil in experimental animal models. J. Medicinal Food. 11 741-746, 2008.

[7] Cheung S., Tai J. Anti-proliferative and antioxidant properties of rosemary Rosmarinus officinalis. Oncology Reports. 17 1525-1531, 2007.

[8] Khatun S., Chatterjee N.C., Çakılcıoğlu U. Antioxidant activity of the medicinal plant Coleus forskohlii Briq African Journal of Biotechnology. 10 2530-2535, 2011.

[9] Tapan S. Quantitative Hplc Analysis of Phenolic Acids, Flavonoids and Ascorbic Acid in Four Different Solvent Extracts of Two Wild Edible Leaves, Sonchus Arvensis and Oenanthe Linearis of North-Eastern Region in India. Journal of Applied Pharmaceutical Science. 6:2 157-166, 2016.

[10] Savcı A., Koçpınar E.F., Alan Y., Kurşat M. Antioxidant, antimicrobial, and DNA protection activities of some Tanacetum species and phenolic richness in their ethanolic extracts. International Food Research Journal. 27:1 160-170, 2020.

[11] Alan Y., Savcı A., Koçpınar E.F., Kurşat M., Topdemir S., Karataş M., Çakmak B. Antimicrobial, antioxidant and DNA protective effects and phenolic content of Lallementia canescens (L.) Fisch. C.A.Mey. and Lallementia peltata (L.) Fisch. C.A.Mey. Biological Diversity and Conservation. 12:3 78-88, 2019.

[12] Hindler J. Tests to Assess Bactericidal Activity. In Clinical Microbiology Procedures Handbook. Ed, Eisenberg Hd. Washington, Dc: American Society For Microbiology. p. 5.16.14-5.16.24, 1992. 
[13] Mitsuda H., Yasumoto K., Wami K. Antioxidative action of indole compounds during the autoxidation of linoleic acid. Eiyoto Shokuryo. 19 210-214, 1966.

[14] Oyaizu M. Studies on product of browning reaction prepared from glucose amine. Jpn J Nutr., 44 307-315, 1986.

[15] Blois M.S. Antioxidant determinations by the use of a stable free radical. Nature. 26 1199-1200, 1958.

[16] Gülçin İ. Antioxidant activity of caffeic acid (3,4dihydroxycinnamic acid). Toxicology. 217:2-3 213-220, 2006.

[17] Londershausen M. Approaches to New Parasiticides. Pesticide Science. 48:4 269-292, 1996.

[18] Köksal E., Tohma H., Kılıç Ö., Alan Y., Aras A., Gülçin I., Bursal E. Assessment of Antimicrobial and Antioxidant Activities of Nepeta trachonitica: Analysis of Its Phenolic Compounds Using HPLC-MS/MS. Sci. Pharm. 85:2 24, 2017.

[19] Milevskaya V.V, Temerdashev Z.A, Butyl'skaya T.S, Kiseleva N.V. Determination of Phenolic Compounds in Medicinal Plants From the Lamiaceae Family. Journal of Analytical Chemistry. 72:3 342-348, 2017.

[20] Cocan I., Alexa E., Danciu C., Radulov I., Galuscan A., Obistioiu D., Morvay A.A., Sumalan R.M., Poiana M. Pop G, Dehelean C.A. Phytochemical Screening and Biological Activity of Lamiaceae Family Plant Extracts. Experimental and Therapeutic Medicine. 15:2 1863$1870,2017$.

[21] Skendi A., Irakli M., Chatzopoulou P. Analysis of Phenolic Compounds in Greek Plants of Lamiaceae Familyby Hplc. Journal of Applied Research on Medicinal and Aromatic Plants. 6 62-69, 2017.

[22] Aras A. Türkiye'de Yetişen Endemik (Nepeta Nuda Subsp. Lydiae) Bitkisine Ait Farklı Ekstrelerin Antioksidan Aktivitelerinin Belirlenmesi ve Fenolik Bileşikiçeriklerinin Lc-Ms/Ms İle Analizi. Doktora Tezi, Fen Bilimleri Enstitüsü, Dicle Üniversitesi, Kimya Anabilim Dalı 105 s, 2016.

[23] Bozkaya Ö. Türkiye'de yetişen bazı phlomis türlerinin in vitro antimikrobiyal aktivitesinin araştırılması. Yüksek Lisans Tezi. Ege Üniversitesi, Sağlık Bilimleri Enstitüsü, İzmir, 2013.

[24] Alan Y., Savcı A., Cakmak B., Kurt H. Determination of the Antimicrobial and Antioxidant Activities of Satureja Hortensis Ingredients journal of the Institute of Natural Applied Sciences. 21:2 167-177, 2016.

[25] Mahmood S., Hayat M.Q., Sadiq A., Ishtiaq S., Malik S., Ashraf M. Antibacterial Activity of Lallemantia Royleana (Benth.) İndigenous to Pakistan. Afr. J. Microbiol. Res., 7:31 4006-4009, 2013.

[26] Öztürk A. In vitro antibacterial activities of Nepeta transcaucasica. Asian Journal of Chemistry, 21:8 64406444, 2009.

[27] Kraujalis P, Venskutonis P.R, Ragazinskiene O. Antioxidant Activities and Phenolic Composition of Extracts From Nepeta Plant Species. Foodbalt. p 79-83, 2011.

[28] Zhang H, Barcelo J.M, Lee B, Kohlhagen G, Zimonjic D.B, Popescu N.C, Pommier Y. Human Mitochondrial Topoisomerase I. Proceedings of the National Academy of Sciences. 98:19 10608-10613, 2001.

[29] Tepe B.A., Degerli S., Arslan S., Malatyali E., Sarikurkcu C. Determination of Chemical Profile, Antioxidant, DNA Damage Protection and Antiamoebic Activities of Teucrium Polium and Stachys İberica. Fitoterapia. 82 237-246, 2011.

[30] Hamza B, Boumediene M, Aicha T.T, Şekeroğlu N. Chemical Composition and DNA Damage Protective Effect of Essential Oil of Rosmarinus Officinalis and Populus Alba. International Journal of Phytopharmacology. 7:4 196-201, 2016.
[31] Guha G., Rajkumar V., Mathew L., Kumar R.A. The Antioxidant and DNA Protection Potential of Indian 25Tribal Medicinal Plants. Turk J Biol., 35 233-242, 2011. 